African Crop Science Journal by African Crop Science Society is licensed under a Creative Commons Attribution 3.0 Uganda License. Based on a work at www.ajol.info/ and www.bioline.org.br/cs

DOI: https://dx.doi.org/10.4314/acsj.v28i1.14S

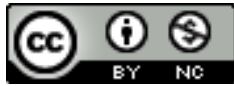

\title{
TREND ANALYSIS OF PRODUCTION, CONSUMPTION AND EXPORT OF CASHEW CROP IN WEST AFRICA
}

\author{
N.P. KOLLIESUAH ${ }^{1}$, J.L. SAYSAY ${ }^{2}$, M.M. ZINNAH ${ }^{3}$, T. A. FREEMAN ${ }^{3,4}$ and D. CHINENYE ${ }^{5}$ \\ ${ }^{1}$ Department of Food Science and Post Harvest Technology, Gulu University, Uganda \\ ${ }^{2}$ World Health Organisation Regional Office for Africa \\ ${ }^{3}$ College of Agriculture and Forestry, University of Liberia \\ ${ }^{4}$ Department of Agricultural Production, Makerere University, P. O. Box 7062, Uganda \\ ${ }^{5}$ Department of Nutrition and Dietetics, Michael Okpara University Umudike, Abia State, Nigeria \\ Corresponding author: kolliesuah44@gmail.com
}

\begin{abstract}
West Africa is a core producer of Cashew (Anacardium occidentale L.), supplying $45 \%$ of the commodity on the global market. Despite this huge share of the international market, only $10 \%$ of the commodity is processed and consumed domestically. The low rate of consumption is reflected by low investment in the cashew industry, making the crop underutilised as a food and nutrition security crop in the region. The objective of this study was to analyse the trends in production, levels of consumption and export of the crop in West Africa, as a basis for informing strategic development interventions. This work utilised metadata from the United Nations Food and Agriculture Organisation database, Nitidae and other relevant sources to explore the production, consumption and export patterns of cashew from the year 2000 up to 2017. The metadata used were analysed using descriptive statistics. The study revealed that eleven (Cote D'Ivoire, Nigeria, Benin, Guinea Bissau, Burkina Faso, Ghana, Mali, Guinea, The Gambia, Senegal, and Togo) of the sixteen countries in West Africa were actively engaged in cashew production. It was also projected that production will decline in the next five years in countries such as Nigeria, Togo, Senegal, and Burkina Faso due to a reduction in the land under cashew cultivation, an increase in pest and disease infestations, coupled with a decline in genetic improvement and poor extension services. Production will remain stable in The Gambia and Guinea Bissau because most trees there are yet to hit the peak of production; and of reduced investment in research and development. Cashew consumption locally is dismal ( $<10 \%$ across the region) due to limited attention given to the processing industry in the region. To boost local production and consumption, as well maintain the $45 \%$ share of the international market in the next five years and beyond, it is essential to invest in genetic improvement, modification of agronomic practices, and investment in the processing industry, as well as research and development of the crop.
\end{abstract}

Key Words: Anacardium occidentale, Cashew, food security, West Africa 
L'Afrique de l'Ouest est l'un des principaux producteurs de Cajou (Anacardium occidentale L.), et elle fournit $45 \%$ de la marchandise sur le marché mondial. Malgré cette énorme contribution sur le marché international, les $10 \%$ des produits sont seulement transformés et consommés sur le marché intérieur. Le faible taux de consommation se traduit par un faible investissement dans l'industrie du cajou, ce qui rend la plante sous-utilisée comme la plante de la sécurité alimentaire et nutritionnelle dans la région. L'objectif de cette étude était d'analyser les taux de la production, les niveaux de consommation et d'exportation de la récolte en Afrique de l'Ouest, comme base pour éclairer les interventions de développement stratégique. Ce travail a utilisé des métadonnées de la base de données de l'Organisation des Nations Unies pour l'alimentation et l'agriculture, Nitidae et d'autres sources pertinentes pour explorer les modèles de production, de consommation et d'exportation de cajou de 2000 à 2017. Les métadonnées utilisées ont été analysées à l'aide de statistiques descriptives. L'étude a révélé que onze pays (Côte d'Ivoire, Nigéria, Bénin, Guinée Bissau, Burkina Faso, Ghana, Mali, Guinée, Gambie, Sénégal et Togo) des seize pays d'Afrique de l'Ouest étaient activement engagés dans la production de cajou. On a également été projeté que la production diminuera au cours des cinq prochaines années dans les pays des Nigéria, Togo, Sénégal et Burkina Faso à cause d'une réduction des terres de cajou, d'une augmentation des infestations de ravageurs et de maladies, et une baisse de l'amélioration génétique et des services de vulgarisation médiocres. La production restera stable en Gambie et en Guinée Bissau parce que la plupart des arbres n'ont pas encore atteint le pic de production; et de la réduction des investissements dans la recherche et le développement. La consommation locale de cajou est lamentable ( $<10 \%$ dans la région) à cause d'une attention limitée accordée à l'industrie de transformation dans la région. Pour stimuler la production et la consommation locales, ainsi que maintenir la contribution de $45 \%$ du marché international au cours des cinq prochaines années et audelà, il est essentiel d'investir dans l'amélioration génétique, la modification des pratiques agronomiques et l'investissement dans l'industrie de transformation, ainsi que la recherche et développement de la culture de cajou.

Mots Clés: Anacardium occidentale, le Cajou, sécurité alimentaire, Afrique de l'Ouest

\section{INTRODUCTION}

Cashew (Anacardium occidentale $\mathrm{L}$ ) is one of the major cash crops in Africa; ranking third in world production of edible nuts. It is a perennial crop belonging to the anacardicaea family and consists of 77 genera and 700 species; of which only 20 of the 700 species are widely distributed in the tropics (Mitra $e t$ al, 2007; Tinalu and Barford, 2008; Trox et al., 2010). Cashew tree has a life span of about thirty to forty years in which it takes about three to four years to reach its full production potentials (Salehi et al., 2019). The raw cashew nut $(\mathrm{RCN})$ is the main commercial product of the cashew tree, though yields of the cashew apple are eight to ten times the weight of the raw nuts (Azam-Ali and Judge,
2001). As a multipurpose species, the cashew apple is used for different purposes. The ethno-medical properties found in the whole part makes it a distinct plant, the leaves, kernel and the fruits are all edible (Prommajak and Leksawasdi, 2014). Products such as cashew apple, nuts and nut shells liquids (NSL) are obtained from the tree and are highly valued on both domestic and international markets (Agboton et al., 2014).

In West Africa, cashew is the second high value export crop after Cocoa (Nitidae, 2019). This has made the region an active player in the global cashew market, with a share of 45\% since 2015 (Monteiro et al., 2017). An estimated 4.2 million metric tonnes of global cashew production in 2012 showcase West Africa's dominance in both the current and 
emerging markets (Adeigbe et al., 2015). Mindful of its value, cashew is considered as a tool responsible for restoring hope to millions of people in Africa given that it is a source of income for many peasant farmers and a boost to national income (Keller, 2010; Sanyang and Kuyateh, 2018).

Despite the region's cashew production potential, literature reveals that cashew apple and nuts account for only $50 \%$ of yield attained from the tree species (Asogwa et al., 2009; Mariwah et al., 2015). Surprisingly, less than $10 \%$ of cashew produced is being processed in the region, implying the regions' high dependence on externally refined products. Moreover, up to $90 \%$ of households growing cashew in the region still live below the poverty line, and thus experience periods of irregular food supply (Adeigbe et al., 2015).

Although scholars have documented West Africa's contribution to the cashew sector in the international market (Mole, 2000; Mashood, 2012), a complete analysis of the production, consumption, and export trends within West Africa is still undocumented. Hence, the objective of this study was to analyse the trends in production, levels of consumption and export of the West African cashew sector, as a basis for informing strategic development interventions.

\section{METHODOLOGY}

The study used cashew production, consumption and export metadata for the West African region (Fig. 1) from 2000 to 2017. The region is the major cashew producing area in Africa, with $45 \%$ share of the global cashew market (Nitidae, 2019). Metadata were extracted from the United Nations Food and Agriculture Organisation (FAO) database, and other relevant literature (FAOSTAT, 2020 and Nitidae, 2019). These datasets were triangulated with already published literature (Monteiro et al, 2017, Adeigbe et al, 2015) and other scientific reports (Kone, 2010; Keller, 2010) to validate the data quality. The data were sorted and cleaned using Microsoft Excel 2013. Descriptive statistics (frequencies and percentages) were performed and summarised into different illustrations.

\section{FINDINGS}

\section{Cashew production trends}

During 2000 - 2017. Table 1 illustrates progress made by eleven countries in cashew production across West Africa. It is apparent that increase in cultivated farmland for cashew hardly resulted into significant elevation in yield for all the countries. Although Cote D'Ivoire, Benin and Guinea Bissau attained the largest area harvested under cashew, average performance in yield was generally lower compared to Nigeria. Nevertheless, Cote D'Ivoire and Nigeria were the top producers of cashew in the region, with individual yields exceeding 340,000 metric tonnes per annum. Despite the fact that the cashew sectors of Guinea Bissau and Benin were affected by pest and disease incidences, and low support from both public and private sectors, they remained the top two countries with average production above 100, 000 metric tonnes after Cote D'Ivoire and Nigeria.

In terms of yearly performance for these countries, Cote D'Ivoire and Nigeria experienced sharp increases of 11.9 and $17.0 \%$, respectively, over the first decade (2000-2010) of the study period (Fig. 2). After 2010, the trend changed with Nigeria producing less than Cote D'Ivoire (Fig. 2). The marked rise in cashew production in Cote D'Ivoire was attributed to significant progress made due to increase in land allocated to cashew cultivation, as well considerable increase in investment from the private sector (World Bank, 2018). From 2000 and 2010, Nigeria also experienced an increase in production as a result of improvement in seed varieties. The difference in the progress between Cote D'Ivoire and Nigeria after this decade can be explained by the level of investment in breeding 


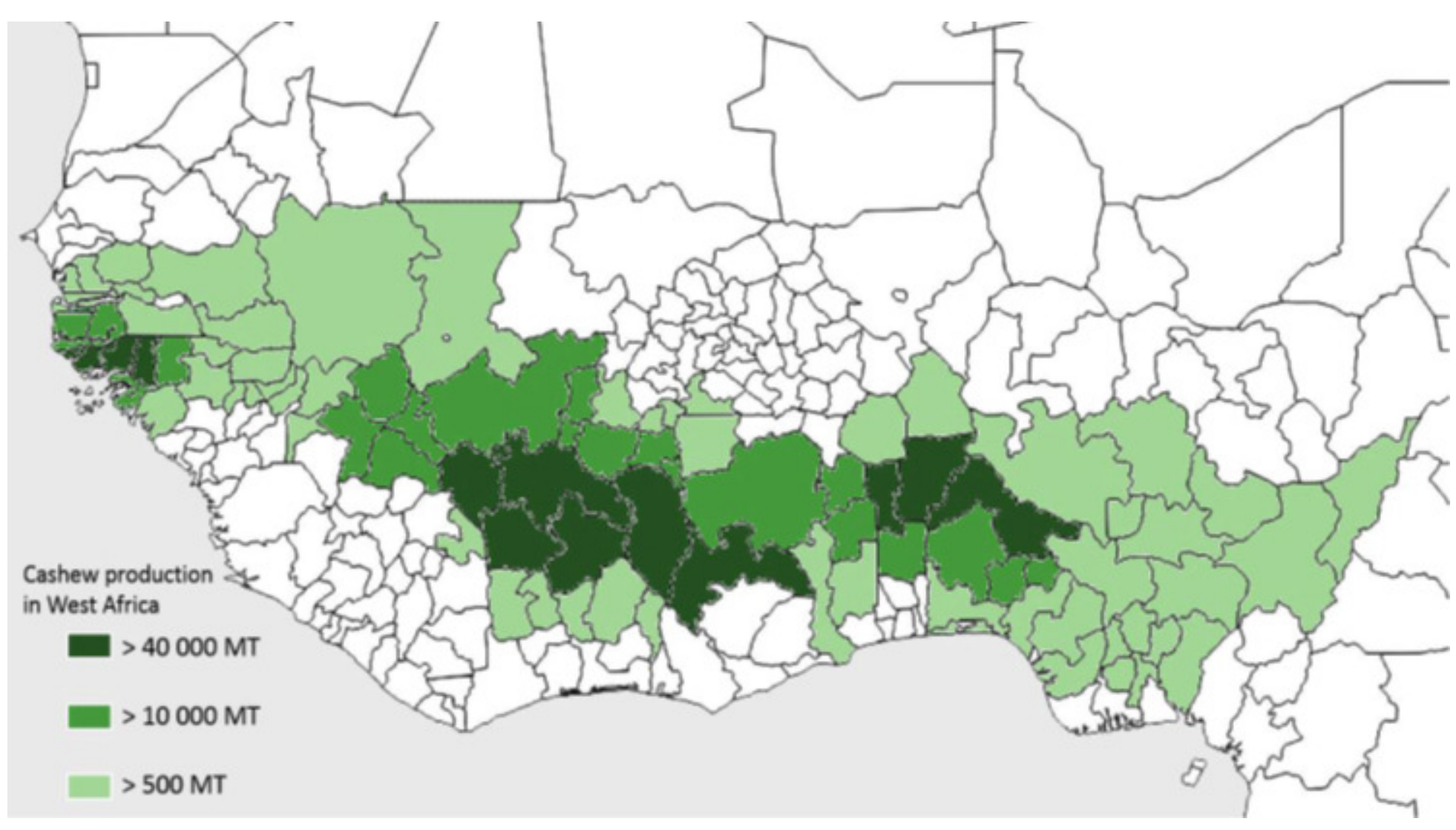

$z$
0
0
0
0
0
0
0
0
0
$\vdots$

Figure 1. Map of the study region. Source: Nitidae (2019). 
Production, consumption and export of cashew crop

TABLE 1. Top producers of Cashew producing countries in West Africa from 2000 - 2017

\begin{tabular}{lccc}
\hline Country & $\begin{array}{c}\text { Area under } \\
\text { Cashew (ha) }\end{array}$ & $\begin{array}{c}\text { Production (metric tonnes) } \\
\text { per annum }\end{array}$ & Ranking \\
\hline Nigeria & 262576.4 & 458982.3 & 1 \\
Cote D'Ivoire & 853355.8 & 345093 & 2 \\
Guinea Bissau & 233148.8 & 114130.8 & 3 \\
Benin & 372754.1 & 106551.6 & 4 \\
Burkina Faso & 47853.9 & 43019.1 & 5 \\
Mali & 22683.9 & 38674.4 & 7 \\
Ghana & 65021.4 & 35051.6 & 8 \\
Guinea & 6125.3 & 6668.2 & 9 \\
Senegal & 18617.1 & 6326.1 & 10 \\
Togo & 2698.3 & 3916.1 & 11 \\
The Gambia & 1901.5 & 1773.5 & 7 \\
\hline
\end{tabular}

Data source: Food and Agricultural Organisation (FAO) 2020 database

technology, which was considerably greater in the former than the latter (Uwagboe et al., 2010). Cote D'Ivoire experienced an increase in investment in genetic improvement by $5 \%$ exceeding Nigeria after 2010 (Calderon et al., 2016). In Nigeria, pests and disease invasion, as well as unimproved planting materials in the second decade contributed to $52-75 \%$ of economic losses (Adeigbe et al., 2015). Net production continued to decline in Nigeria, accumulating to $11.6 \%$ of total production in 2017 , compared to production in the last seven years (Adeigbe et al., 2015). Nigeria, being one of the countries on the production frontier, and key in the cashew market, it is becoming more of concern as economic growth and productivity for the large segment of the rural population is expected to decline, thus affecting the country's national revenue.

In Guinea Bissau and Benin, production increased from 4 and $3.1 \%$ to 7.64 and $7 \%$, respectively, from 2007 to 2014 . The trend in the two countries was similar to that in Cote D'Ivoire where there was a significant increase in production due to an increase in acreage of the crop with huge support from the governments and many non-governmental organisations (NGOs) (Monteiro et al., 2017).
However, the unexpectedly slower rate of production in the two countries was premised on the relatively higher cost of production, especially in terms of labour for weeding and harvesting. Until the opportunity for investment in mechanisation are realised, steady growth will remain challenged. These indicators illustrate that few countries in the West African region (Cote D'Ivoire, Nigeria, Guinea Bissau and Benin) performed extremely well to increase productivity of the tree species Fig. 2).

Period post-2017. Projections of cashew production five years after 2017 in West Africa are presented in Figure 3. It is clear that Cote D'Ivoire is expected to remain the lead producer of cashew in West Africa in the next five years. This will be followed sequentially by Ghana, Guinea and Mali. Nigeria's production is expected to further decrease by $18.9 \%$, as will be the case for Burkina Faso, Togo and Senegal (though in reducing magnitudes). The decline in Senegal will likely be due to the nominal total area $(<1 \%)$ under cashew cultivation (Kahlmann and Kohn, 2018). The projected decrease in Nigeria will be attributed to decline in genetic improvement 


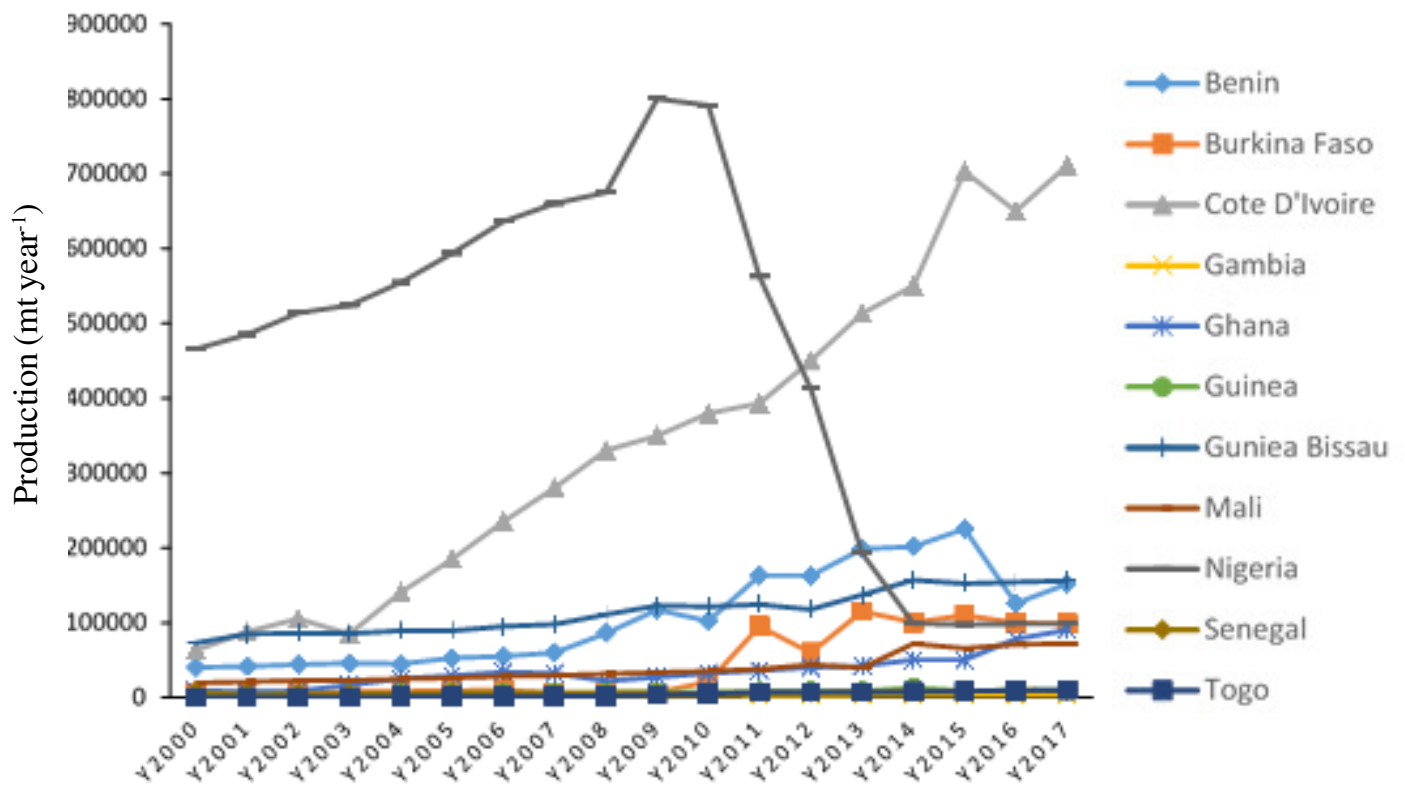

Figure 2. Trends in the production of cashew across West Africa over the period of $2000-2017$. Source: Food and Agricultural Organisation (FAO) 2020 database.

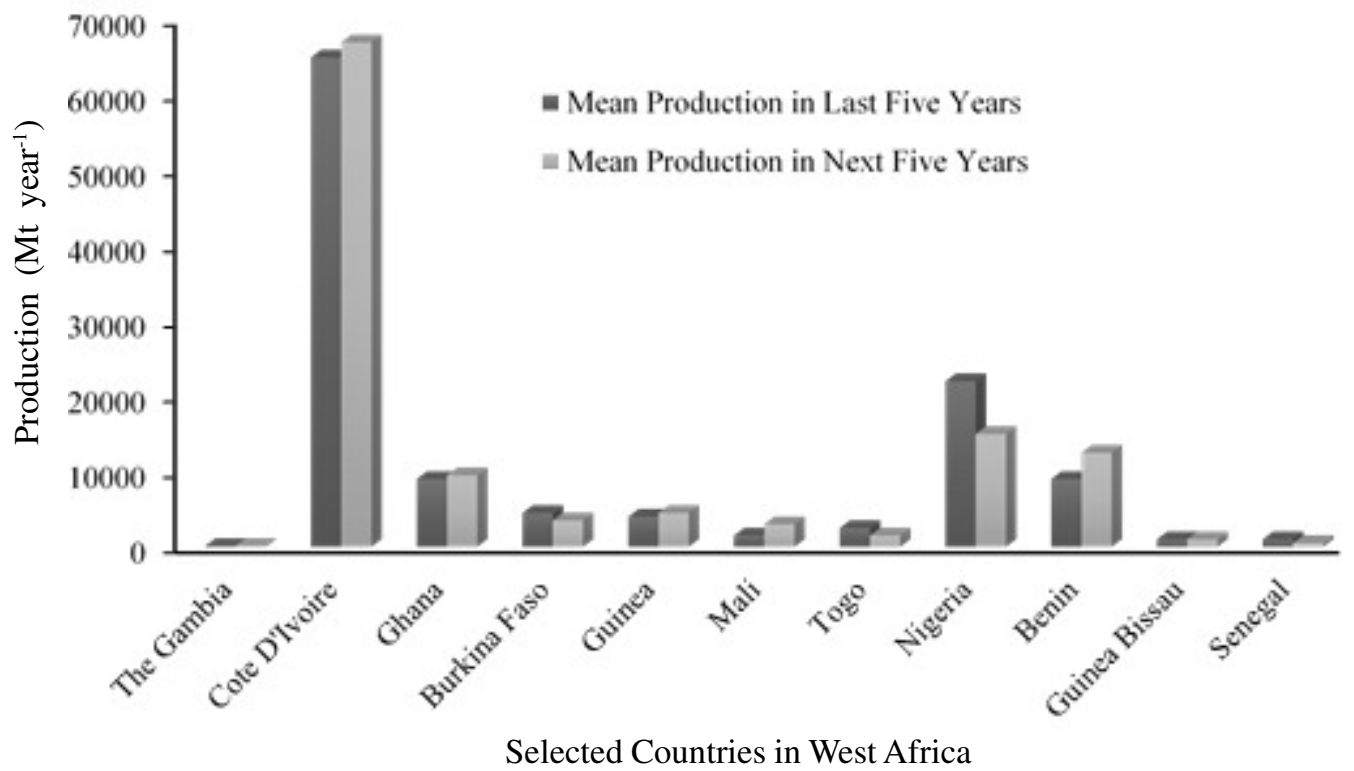

Figure 3. Production of cashew in previous five years against production forecast in the next five years after 2017, disaggregated by countries in West Africa as of 2018. Source: (Nitidae, 2019). 
efforts as a result of limited investment in genetic research and development (Mashood, 2012). This projection illustrates that, although countries such as Ghana, Guinea and Mali are actively investing in research to improve the genotype of the species, Nigeria seems to be lagging behind in this effort (Adeigbe et al., 2015).

Cashew production in Burkina Faso and Togo was expected to decrease owing to inadequate knowledge and poor extension services related to this crop in both countries (Dendena and Corsi, 2014). Although peasant farmers in the region did their best to increase production over the study period, they were stunned by pests and disease infestations (Monteiro et al., 2017). This was attributed to insufficient knowledge on the use of crop protection strategies (Adjrah et al., 2013).

In The Gambia and Guinea Bissau, it was projected that production would remain static because most of the trees are yet to hit the peak of production (Catarino et al., 2015). In addition, research and extension efforts related to improved planting materials were scanty in these countries for one to be able to ascertain the production level from an informed perspective (Kahlmann and Kohn, 2018). Moreover, the cashew value chain in The Gambia, Guinea Bissau, and Senegal was constrained by limited access to finance, inappropriate application of best practices, and the absence of established market information systems (Paviot et al., 2019)

From all indications, it is clear that the trend of cashew production in the last eighteen years (2000-2017) in West Africa has been fluctuating. Although Cote D'Ivoire, Guinea Bissau and Benin experienced marked increases in production of the crop, Nigeria, Togo, Senegal, Mali and The Gambia remained in the lower limits of production; with projections of decline for Nigeria, Senegal, Togo and Burkina Faso in the next five years. These scenarios imply that concerted efforts are needed in terms of research and development, public-private investment, genetic improvement and increase in extension services to raise production in these countries.

\section{Consumption of cashew}

Period 2000-2017. Cashew consumption in the West African region based on different national scales is presented in Figure 4. Despite decline in production trends for Nigeria, the country remains the highest consumer of the crop in the region, with an average of 428,809.1 tonnes per annum during the study period. Even though Cote D'Ivoire was the largest producer of cashew, the country ranked fourth in terms of consumption of the crop (Fig. 4). Mali and Benin were the second and third consumers after Nigeria (Fig.4).

Trend analysis shows that cashew consumption increased markedly across the eleven active countries, from 2000 to 2010 (Fig. 5). Nigeria, Mali and Guinea Bissau were the top three countries in this sequence. In these three countries, production and consumption of cashew were closely parallel in the first decade preceding 2010. In addition, during the same period, less than $10 \%$ progress was recorded in efforts made towards implementing value addition in the region (Tola and Mazengia, 2019). As production dropped steadily in these countries in 2011 and beyond, a downward shift in cashew consumption was observed across the region, until it stabilised in 2014. The decrease in consumption in these three countries in 2011, can be explained by the general reduction in production and local processing. Apart from the fact that most of the cashew trees in Nigeria had outlived the supposed productive age of 30 years, a study by Asogwa et al., (2008) revealed that $60 \%$ of the plants had reached this bench, but were still stressed to yield fruits and nuts for commercial purposes. On the other hand, the initial increase in local consumption in Nigeria was attributed to a drop in value on the international market.. To avoid a decline in national growth, national governments tend to prioritise local 


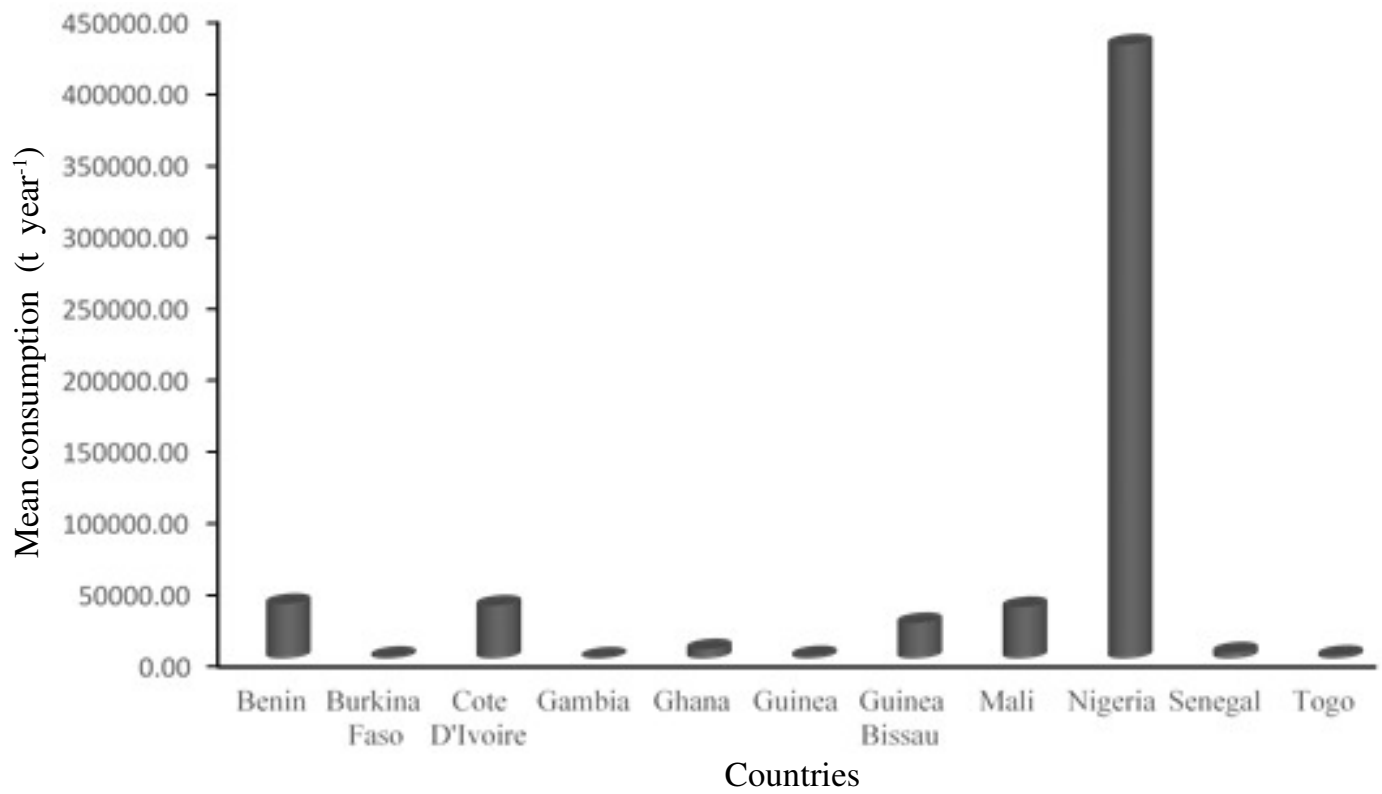

Figure 4. Top cashew consumer countries in West Africa during 2000 - 2017; Source: Food and Agricultural Organisation (FAO) 2020 database.

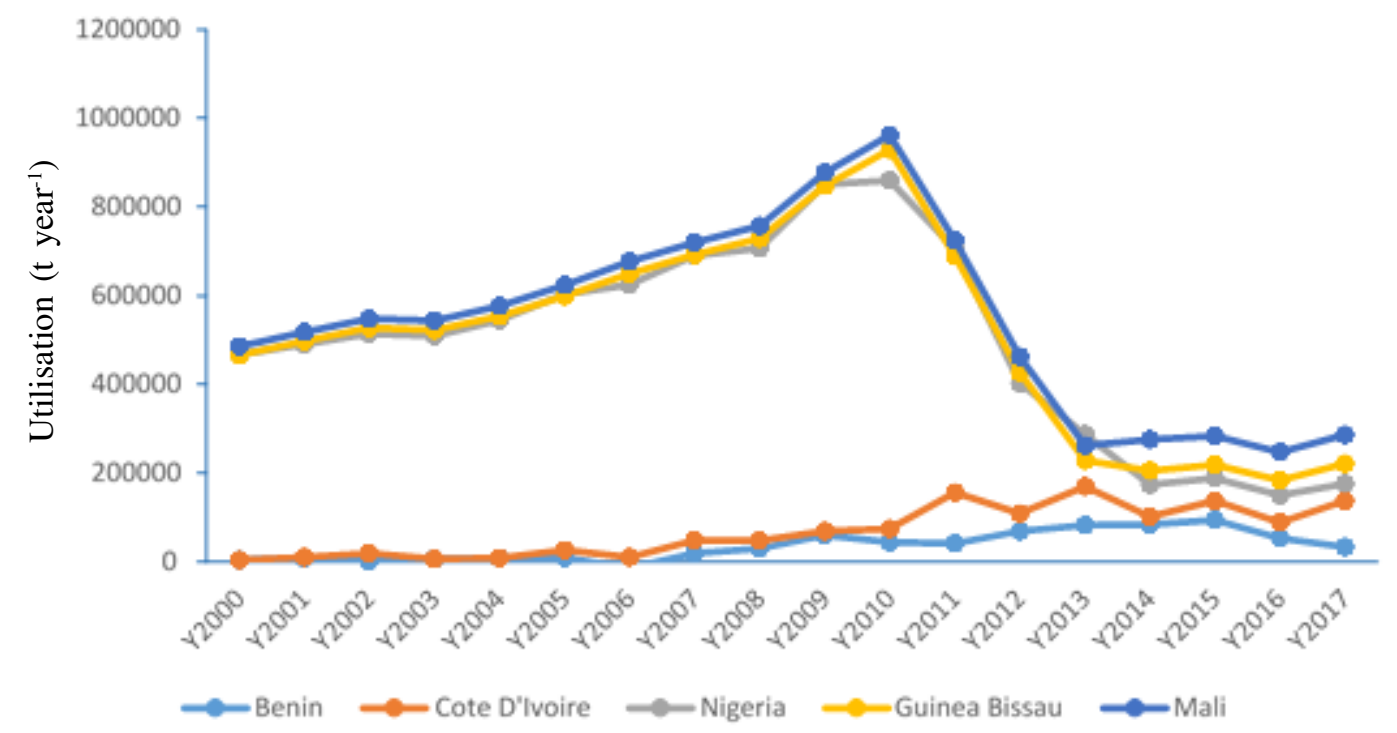

Figure 5. Trends in the use of cashew across West Africa over the period of 2000 - 2017. Source: Food and Agricultural Organisation (FAO) 2020 database. 
processing industry to increase its national processing capacity (Nitidae, 2019).

Cote D'Ivoire and Benin made very little progress in local cashew consumption at less than 200, 000 tonnes since 2000 (Fig.5). In Cote D'Ivoire, cashew processing and value addition were both still in their infancy. More so, the country was constrained by insufficient finance to construct modern processing facilities. This impediment prompted Cote D'Ivoire to embark on exportation of the raw materials to India (71\%) and Vietnam (28\%) (Koné, 2010). In 2017, the country reached a capacity of 109,500 metric tonnes of raw materials for the local processing industry (Koné, 2010; Nitidae, 2019). SITA, the largest processing company had less than $50 \%$ capacity to process the cashew nuts.

In Benin, the cashew apple had long been considered as waste in the processing industries due to its soft and fragile nature (Preethi et al., 2019). This was mostly hinged on dismal investment in the processing industries (Fig. 5). Also, there were less than eleven processing industries in the country, with less than 1000 metric tonnes capacity to process the commodity (Nitidae, 2019). On the other hand, the country still struggled to raise production above 240,000 metric tonnes per year (Fig. 2). This indicates that raw materials for the processing industries were bottlenecks. Amidst these scenarios, it is evident that very little efforts had been made to explore the cashew value chain in Cote D'Ivore and Benin.

The sharp reduction in consumption of cashew in Mali and Guinea Bissau as of 2011 is attributed to constraints in production such as unimproved planting materials and poor agronomic practices as noted by Oluyole and Abbas (2016). This resulted from damage caused by different insect species during the stages of production, which made the quality unsuitable for processing. Furthermore, the stability in the consumption trend was hinged on marketing constraints as a result of lower output and poor quality products.

\section{Rate of consumption}

The rate of cashew consumption is a function of the quantity of the cashew consumed domestically (Fig. 5) and the total population at a defined period (Kearney, 2010). It provides an elaborate understanding of the proportion of the commodity being consumed nationally. The rate of consumption of cashew was tabulated using the formula shown below with results presented in Figure 6:

$\mathrm{R}_{\mathrm{c}}=\frac{\text { Quantity of Cashew consumed locally }}{\text { Total population as of } 2018} \times 100 \%$

Where:

$\mathrm{R}_{\mathrm{c}}=$ Rate of consumption

Across the entire region, rate of consumption of the cashew was less than $10 \%$ (Fig.6). In terms of trend analysis over the years, it was clear that even countries at the highest extreme of production and processing, equally utilised smaller proportions of the commodity (Fig. $6)$. On the other hand, those at the lower limit of production like Guinea Bissau and Benin did better. Despite the low rate of consumption across the entire region, Guinea Bissau utilised 3.62 and $2.34 \%$ of the total commodity produced domestically in 2010 and 2017, respectively; making it the highest consumer in the region for the period under study. Although the study indicated that in 2010, Nigeria was leading in production and processing, its rate of consumption lagged behind Guinea Bissau by $0.40 \%$ when compared to the rest of the countries. Benin also attained its peak of consumption in 2012 and 2015 , with 0.62 and $0.82 \%$, respectively.

Conversely, as production started to increase steadily across countries from 2002 to 2017 , the rate of consumption declined considerably (Fig. 6). To a great extent, this shows that cashew was being underutilised in 


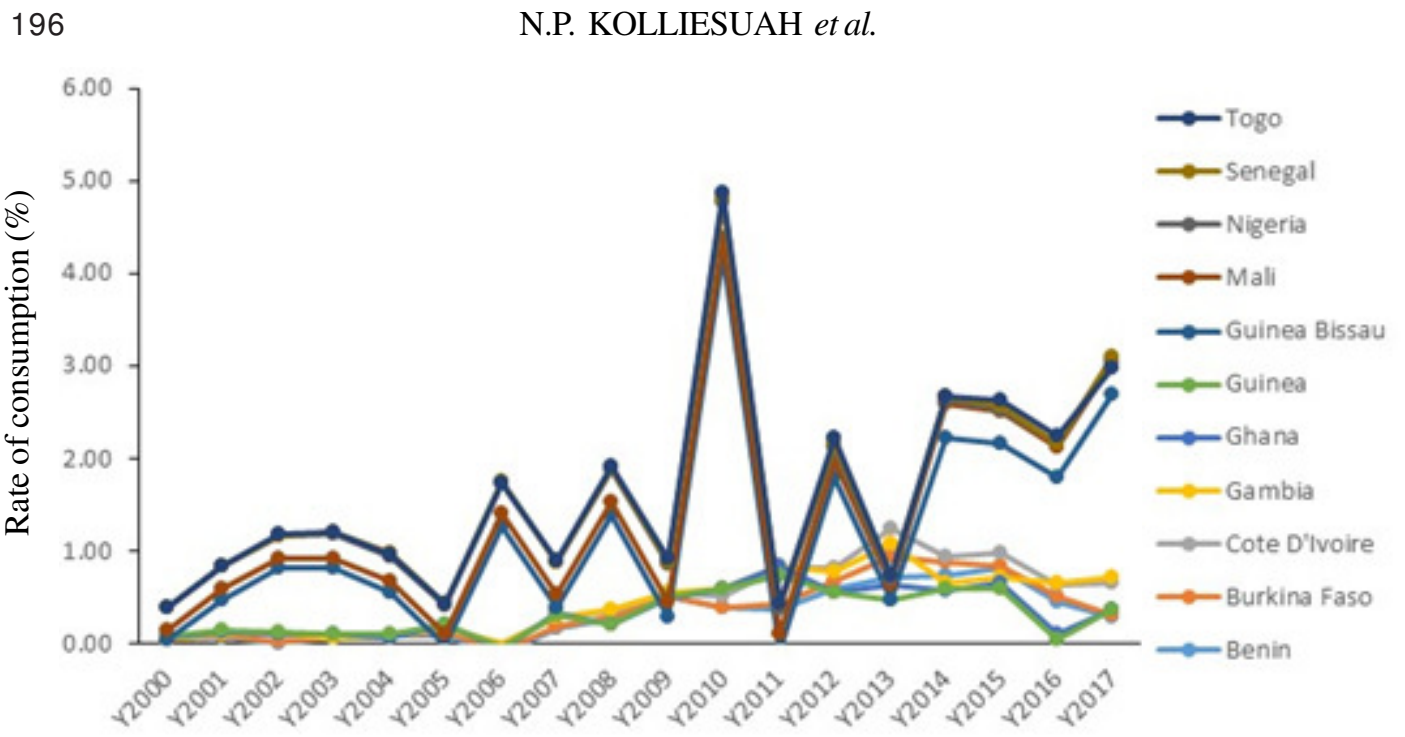

Figure 6. Rate of consumption of the cashew across West Africa over the period of 2000 - 2017. FAO database (2019) and Nitidae (2019).

the region. This can be explained by the limited capacity in value addition across these countries, as less than $10 \%$ of cashew nuts underwent value addition domestically in the region (Tola and Mazengia, 2019). Only a few countries in the region (Mali, Guinea Bissau, Nigeria and Benin) attached value to the species (Nitidae, 2019). Guinea Bissau also used the commodity in its fresh form in feeding livestock; and the raw material to produce juices, jams, vinegar, candy, salad and syrup (Brufau et al.,, 2006; Vivek et al., 2013; Nwosu et al., 2016). Although this trend kept shifting, there was evidence that countries at the higher end of production mostly prioritised export of the cashew in an unrefined form $(80 \%)$, compared to countries with a small proportion of the commodity produced (Keller, 2010). It can, therefore, be reasoned that the commodity was underutilised in the West African region, with dismal attention given to the processing industry. Despite its monetary contributions from the international market, the region still greatly misses out on value-added income from domestic trades and its nutritional benefits.

\section{Cashew export projections}

Based on the statistics in Figure 7, Cote D'Ivore was the largest exporter of cashew in the region with an average of 312, 200.7 tonnes; followed by Guinea Bissau, Benin and Ghana. The increase in export potential was as a result of increase in production due to expansion in area cultivation and private investment in the sector (Keller, 2010).

Figure 8 presents trend analysis for the quantity of cashew exported by selected West African countries. Cote D'Ivore was the largest producer in the region, and also maintained the largest share of the export market since 2011. Similarly, Nigeria experienced a peak of 118,977 metric tonnes of export in 2012; the highest volume of cashew trade in Nigerian history. Thereafter, Nigeria's cashew export started to slump in 2013 through 2017. This can be attributed to the numerous losses due to diseases and insect pests during production and distribution, as already explained earlier.

It is worth putting on record that countries such as The Gambia, Togo, and Mali have no 


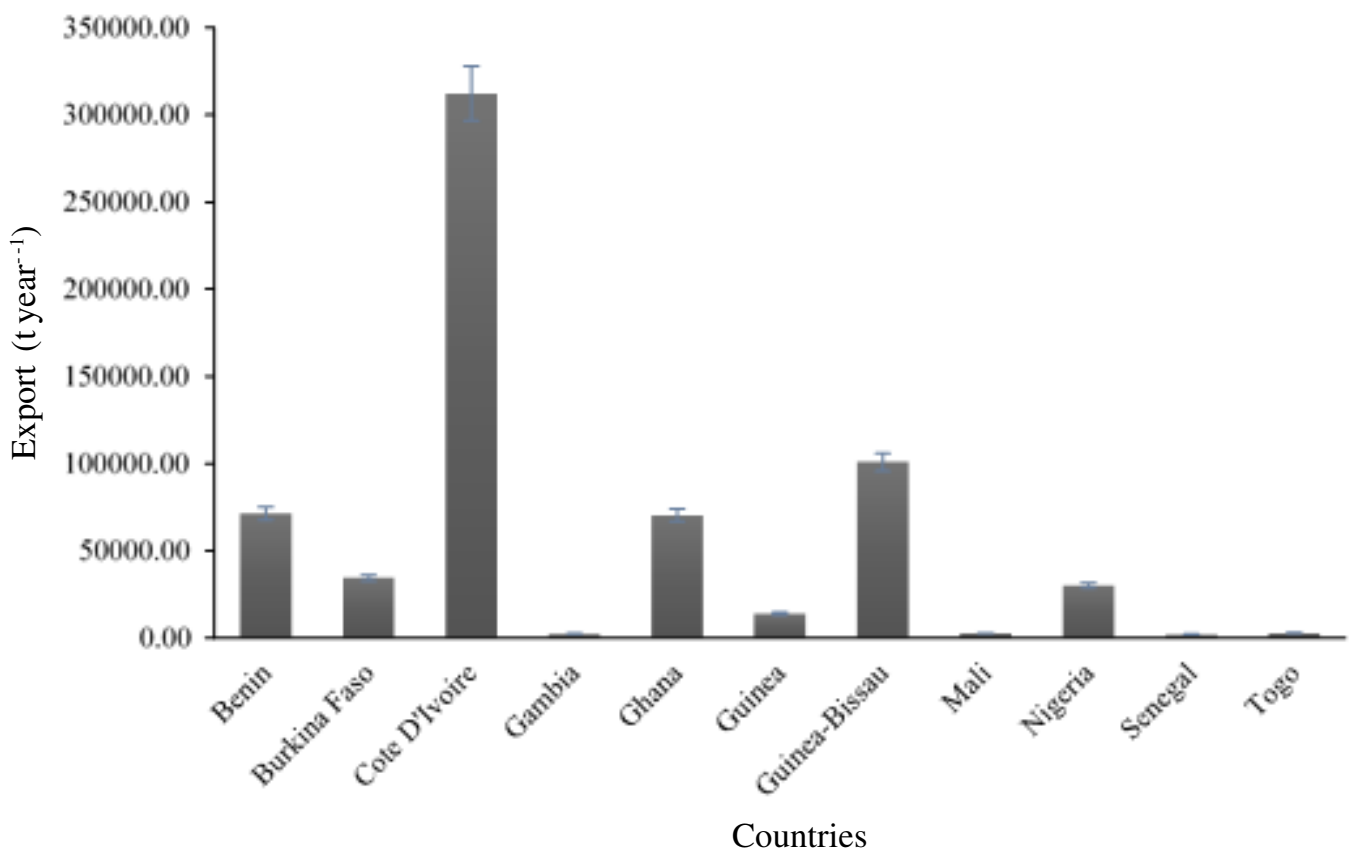

Figure 7. Mean quantity of cashew (tonnes) exported per annum across representative West African countries (2000-2017). Source: Food and Agricultural Organisation (FAO) 2020 database.

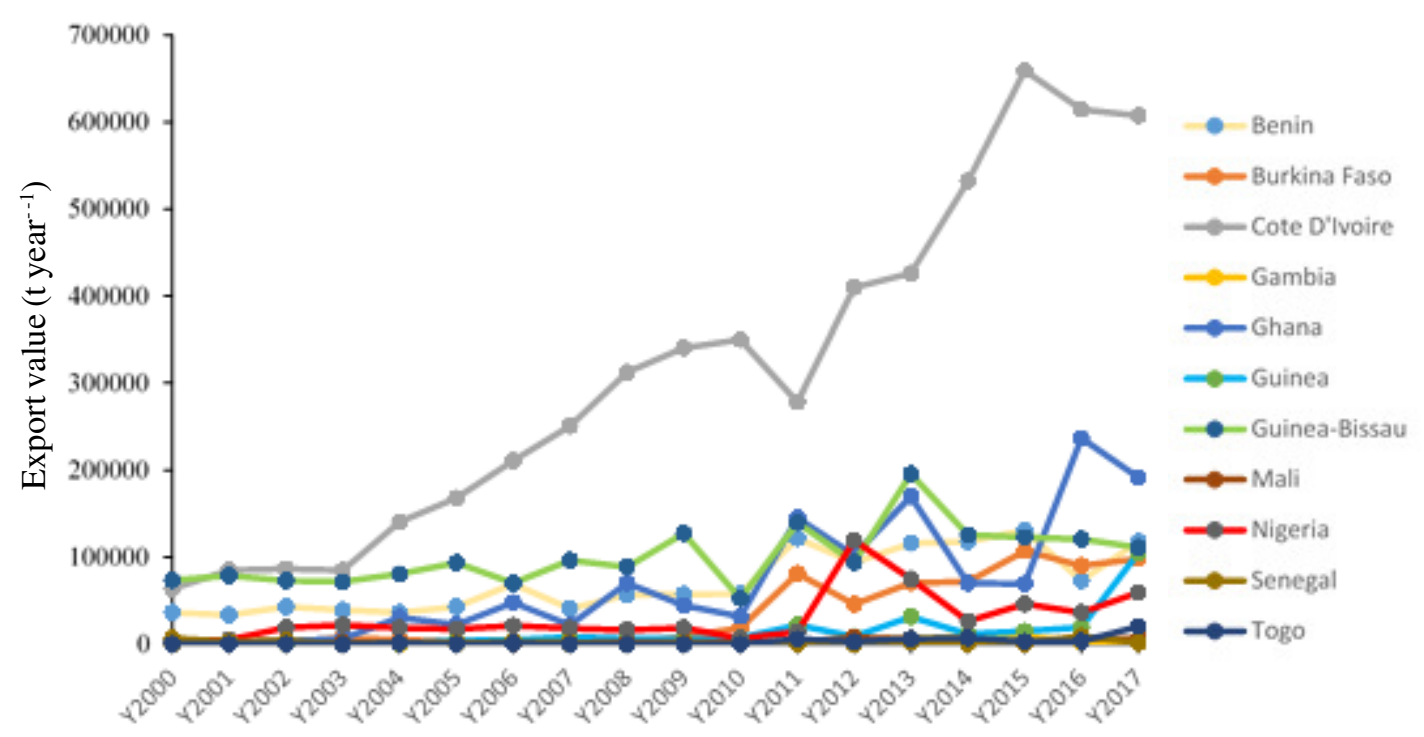

Figure 8. Trend of the Quantity of Cashew exported from West Africa from 2000 - 2017 Source: FAOSTAT (2019). 
export history between 2000 and 2007, perhaps due to reduced production. Advancement in research and development was made to enhance the production of cashew in these countries; thus exports increased between 2008 and in 2017 (Fig. 8). Although projection for the cashew market shows that production is expected to decline in Nigeria, Senegal, Togo, Guinea, and Burkina Faso (Fig. 3 ), it presents fascinating facts that these countries will increasingly find it demanding to trade with Vietnam and India due to a reduction in the demand for their goods and facilitating prices (Kilama, 2009).

In terms of share in the West African cashew export market, Vietnam accounted for 929,500 metric tonnes in 2018, while India which ranked second was responsible for 711,000 metric tonnes (Fig. 9). All active cashew countries in West Africa exported more than $80 \%$ of the commodity to these countries; with less than $10 \%$ being processed locally (Tola and Mazengia, 2019). This limitation in value addition will lead to a reduction in the profit margin by approximately 60 percent of value-added income in the next five years
(Kahlmann and Kohn, 2018). This, therefore, suggests that countries whose national incomes and growth are reliant on this as a cash crop will experience shrinkage in national income (Fynn, 2004), given that cashew contributes to $25.6,7.1,6.1$ and $3 \%$ of the GDP in Cote D'Ivoire, Guinea Bissau, Ghana and Benin, respectively (Keller, 2010; Koné, 2010).

As a result of this decline, it is expected that the reduction in growth will severely affect rural farmers thereby dragging many into hunger and poverty. This will consequently undermine progress toward achieving the United Nations Sustainable Development Goals (SDGs) of zero hunger and no poverty in these countries. India and Vietnam will also be impacted by the decline in production since these two receive the largest share of the commodity from West Africa.

It is important to also note that in the next four years, the demand for cashew on the international market will grow to over three million metric tonnes, ceteris paribus (Monteiro, 2017). This presents an interesting picture for West Africa to utilise the market in maximising profits, at the detriment of the

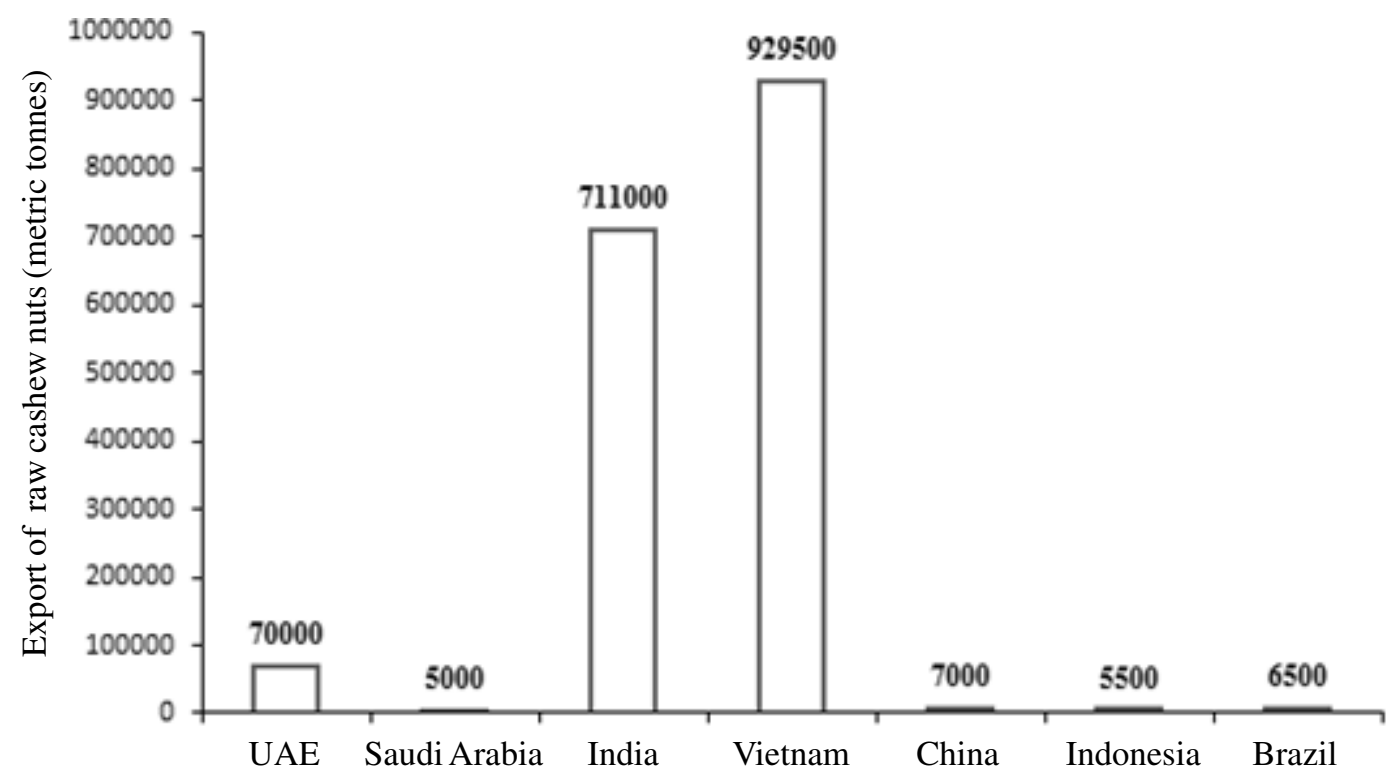

Figure 9. Average Shares of exports in tonnes gained by top cashew processing countries globally (FAOSTAT, 2019) and Nitidae (2019). 
reduction in cashew produced in India and Vietnam in the next five years. However, this is only feasible if advances are made in research and extension as well as investment in processing across the region. West Africa needs to grow an average of 8 to $16 \%$ per annum to meet this demand (Mariwah et al., 2015).

\section{CONCLUSION}

Cashew production has been on the increase in West Africa with eleven countries being active in production. Cote D'Ivoire and Nigeria are the dominant producers of cashew in the region; followed by Benin and Guinea Bissau in the last two decades (2000 to 2017). However, the average production of cashew is expected to decline in the next five years in countries such as Nigeria, Togo, Senegal, and Burkina Faso as opposed to The Gambia and Guinea Bissau where production is expected to remain nearly stable. The decline in production in these countries will be mainly due to rudimentary farming practices, limited investment in genetic modification, inadequate public-private investment in the value chain, and limited extension services. In quantitative terms, less than $10 \%$ of the cashew produced in the region underwent processing, especially value addition due to limited investment in the processing industry. Mali, Guinea Bissau, Nigeria, Cote D'Ivoire, and Benin are the five countries at the forefront of local consumption with Cote D'Ivoire, Guinea Bissau, Ghana, and Benin owning the largest share of the export market.

Based on the analysis and considering the importance of cashew in livelihood enhancement of smallholder farmers, the growth and development of large trade based institutions and countries, it is essential to invest in the production and processing of cashew. Increase in production and productivity requires both technical and financial support focused on farmers' capacity building on improved agronomic practices, harvest and post-harvest practices as well as research and extension services in the areas of genetic improvement and pest management. For processing and value addition, it entails technical and business skills, access to finance and investment in cashew processing industries. Besides, public-private partnerships will be essential in providing the needed resources to smallholder farmers for cashew production, processing, and marketing. With the above recommendations in place, West Africa will contribute greatly in meeting the expected over 3 million tonnes of cashew demand in the next four years on the international market.

\section{ACKNOWLEDGEMENT}

The authors are grateful to the MasterCard Foundation and Regional Universities Forum for Capacity Building in Agriculture (RUFORUM) for funding research and publication cost through the Transforming African Agricultural Universities to meaningfully contribute to Africa's growth and development (TAGDev) Program.

\section{REFERENCES}

Adeigbe, O.O., Olasupo, F.O., Adewale, B.D. and Muyiwa, A.A .2015. A review on cashew research and production in Nigeria in the last four decades. Scientific Research and Essays 10(September 2016):196-209. doi: 10.5897/SRE2014.5953.

Adjrah, Y., Dovlo, A., Karou, S.D., EkluGadegbeku, K., Agbonon, A., Souza, C. and Gbecissor, M. 2013. Survey of pesticide application on vegetables in the Littoral area of Togo. Annals of Agricultural and Environmental Medicine 20(4):715-720.

Agboton, C., Onzo, A., Ouessou, F.I., Goergen, G., Vidal, S. and Tamo, M. 2014. Insect fauna associated with anacardium occidentale (Sapindales: Anacardiaceae) in 
Benin, West Africa. Journal of Insect Science 14. doi: 10.1093/jisesa/ieu091.

Asogwa, E. U., Anikwe, J.C., Ndubuaku, T.C.N. and Okelana, F.A. 2009. Distribution and damage characteristics of an emerging insect pest of cashew, Plocaederus ferrugineus L. (Coleoptera: Cerambycidae) in Nigeria: A preliminary report. African Journal of Biotechnology 8(1):053-058. doi: 10.4314/ajb.v8i1.59732.

Asogwa, E. U., Hammed, L. A. and Ndubuaku, T.C.N. 2008. Integrated production and protection practices of cashew (Anacardium occidentale) in Nigeria. African Journal of Biotechnology 7(25): 4868-4873. doi: 10.4314/ajb.v7i25.59681.

Azam-Ali, S.H. and Judge, E.C. 2001. Smallscale cashew nut processing. Rugby, UK: Food and Agriculture organization. (30 October 2013):1-70.

Bezerra, C.F., Silva, T.G., Coutinho, H.D.M., Amina, B., Armstrong, L., Selamoglu, Z., Sevindik, M., Yousaf, Z., Sharifi-Rad, J., Muddathir, A.M., Devkota, H.P., Martorell, M., Jugran, A.K., Martins, N., Cho, W.C. 2019. Anacardium Plants/: Chemical, Nutritional Composition and Biotechnological Applications. Biomolecules 9(September): 1-34. doi: 10.3390/biom9090465.

Bezerra, M. A., de Lacerda, C.F., Filho, E.G., de Abreu, C.E.B. and Prisco, J.T. 2008. Physiology of cashew plants grown under adverse conditions. Brazillian Journal of Plant Physiology 19(4):449-461.

Brufau, G., Boatella, J. and Rafecas, M. 2006. Nuts: Source of energy and macronutrients. British Journal of Nutrition 96(2). doi: 10.1017/ BJN20061860.

Calderon, C., Kambou, G., Cantu, C., Catalina, K. and Vijidan, K.M. 2016. An Analysis of Issues Shaping Africa's Economic Future. Africa's pulse. October 2016 (20). https:/ /openknowledge.worldbank.org/handle/ $10986 / 32480$
Catarino, L., Menezes, Y. and Sardinha, R. 2015. Cashew cultivation in Guinea Bissaurisks and challenges of the success of a cash crop. Scientia Agricola 72(5):459-467

Dendena, B. and Corsi, S. 2014. Cashew, from seed to market/ : A review. Agronomy for Sustainable Development 34(1):753-772. doi: 10.1007/s13593-014-0240-7.

FAOSTAT. 2019. Food and Agricultural Organization of the United Nations Statistics Division. Available online: http:// faostat3.fao.org/download/Q/QC/E (accessed on 10 February 2020)

FAOSTAT. 2020. Food and Agricultural Organization of the United Nations Statistics Division. Available online: http:// faostat3.fao.org/download/Q/QC/E (accessed on 10 February 2020)

Fynn, J. 2004. Policy and Taxes in the Tanzanian Cashew Industry. DAIPesa, (October). 1-85.

Kahlmann, K. and Kohn, M. 2018. USDA/FAS Food for Progress: SeGaBi Cashew Value Chain Study. USDA technical report. https:/ /www.climatefinancelab.org/wp-content/ u p lo a d s / $2018 / 12 / \mathrm{S} \mathrm{e} \mathrm{G} \mathrm{a} \mathrm{B} \mathrm{i} \mathrm{-}$ study_final_18.03.02_pub.pdf .

Kearney, J. 2010. Food consumption trends and drivers. Philosophical Transactions of the Royal Society B: Biological Sciences 365(1554):2793-2807. doi: 10.1098/ rstb.2010.0149.

Keller, P. 2010. A Value Chain Analysis of the Cashew Sector in Ghana. African Cashew initiative. https://agoa.info/images/ documents/5130/Chashew_valuechain analysis_Ghana.pdf

Kilama, B. 2009. Crisis Responses in the Cashew Industry/ : A Comparative Study of Tanzania and Vietnam. Cambriage Journal of Economics 1-23.

Koné, M. 2010. Analysis of the Cashew Sector Value Chain in Côte d' Ivoire. Africa Cashew Initiative 1-35.

Mariwah, S., Evans, R. and Antwi, K. B. 2015. The shift towards cashew cultivation: Impacts on livelihoods, poverty alleviation 
and household food security in BrongAhafo region, Ghana. Extended Abstract. University of Cape coast. 1-4.

Mashood, O. 2012. Genetic Diversity of Nigerian Cashew Germplasm. Genetic Diversity in Plants 1-24. doi: 10.5772/ 32892.

Mitra R., Mitchell B., Gray C., Orbell J., Coulepis T. and Muralitharan M .2007. Medicinal Plants of Brazil. Asia Pac Biotech News 11:689-706.

Mole, P. 2000. Economic analysis of Smallholder Cashew development opportunities and linkages to food security in Mozambique's Northern Provice of Napula. PhD. Thesis, Michigan State University, USA. 275pp

Monteiro, F., Catarino, L., Batista, D., Indjai, B., Duarte, M.C. and Romeiras, M.M. 2017. Cashew as a High Agricultural Commodity in West Africa/ : Insights towards Sustainable Production in GuineaBissau. Sustainability 1-14. doi: 10.3390/ su9091666.

Nitidae. 2019. The West African Cashew Sector in 2018: General trends and country profiles. Nitidae report. pp. 1-15.

Nwosu, C., Adjumo, O. A. and Udoha, W.N. 2016. Cashew apple utilization in Nigeria/ : Challenges and prospects. Journal of Stored Products and Postharvest Research 7(2):29-31. doi: 10.5897/JSPPR2015.0190.

Oluyole, K. A. and Abbas, A. 2016). Evaluation of the Post-Harvest Loss of Cashew Apple among Cashew Farmers Esxon Publishers. International Journal of Applied Research and Technology 5(2):71-77.

Paviot, M. C., Bresnyan, E.W., Grosclaude, M., Ba, A., Diaz, A. and Mishu, S. 2019. Guinea Bissau/: Unlocking diversification to unleash agriculture growth. World bank report. http://documents1.worldbank.org/ curated/en/341991563831364596/pdf/ Guinea-Bissau-ASA-Agriculture-sectorReport.pdf.(accessed 4 April 2020)

Preethi, P., Rajkumar, A.D., Shamsudheen, M. and Nayak, M.G. 2019. Prospects of Cashew Apple - A Compilation Report, Technical Bulletin No. 2/2019. ICAR-Directorate of Cashew Research, Puttur, Karnataka, India. 28pp.

Prommajak, T. and Leksawasdi, N. 2014. Biotechnological Valorization of Cashew Apple/ : A Review. Journal of Natural Science 13(2):159-189. doi: 10.12982/ cmujns.2014.0029.

Salehi, B., Gültekin-Özgüven, M., Kýrkýn, C., Özçelik, B., Morais-Braga, M.F.B., Carneiro, J.N.P., Bezerra, C.F., Silva, T.G., Coutinho, H.D.M., Amina, B., Armstrong, L., Selamoglu, Z., Sevindik, M., Yousaf, Z., Sharifi-Rad, J., Muddathir, A.M., Devkota, H.P., Martorell, M., Jugran, A.K., Martins, N. and Cho, W.C. .2019. Anacardium Plants/: Chemical, Nutritional Composition and Biotechnological Applications. biomolecules. 9(September): 1-34. doi: 10.3390/biom9090465.

Sanyang, S.E. and Kuyateh, E. 2018. Cashew production as livelihood improvement to small-holder producers in North Bank region of the The Gambia. Asian Journal of Agricultural Extension Economics \& Sociology, 28(1): 1-7. doi: 10.9734/ajaees/ 2018/22750.

Tianlu, M. and Barfod, A. 2008. Flora of Anacardiaceae Plant in China. Missouri Botanical Garden Press 11: 335-357.

Tola, J. and Mazengia, Y. 2019. Cashew production benefits and opportunities in Ethiopia: A Review. Journal of Agricultural and Crop Research doi: 10.33495/jacr.

Trox, J., Vadivel, V., Vetter, W., Stuetz, W., Scherbaum, V., Gola, U., Nohr, D. and Biesalski, H. 2010. Bioactive compounds in cashew nut (Anacardium occidentale $\mathrm{L}$.) Kernels/ : Effect of Different Shelling Methods. Journal of Agricultural and Food Chemistry 88(1):5341-5346. doi: 10.1021/jf904580k.

Uwagboe, E.O., Adeogun, S. O. and Odebode, S.O. 2010. Constraints of farmers in cashew production: A case study of Orire L.G.A. of Oyo State, Nigeria. ARPN 
Journal of Agricultural and Biological Science 5(4): 27-31.

Vivek, M., Manasa, M., Pallavi, S., Sachidananda, S.H.C. and Prashith, K. 2013. Antibacterial potential of cashew apple (Anacardium occidentale L.) Juice
Against Clinical Isolates of Staphylococcus aureus and Streptococcus mutans. Science, Technology and Arts Research Journal 2(3):144. doi: 10.4314/star.v2i3. 98756.

World Bank. 2018. Combined project information documents/integrated safeguards. World bank report. Report No: PIDISDSA21985. 